\title{
Polska pamięć wielokierunkowa? (Kto nie pamięta z nami, ten nie pamięta przeciwko nam)
}

Katarzyna Bojarska

TEKSTY DRUGIE 2016, NR 6, S. 312-325

DOI: $10.18318 /$ td.2016.6.18

W ydarzenie historii globalnej dotyczące tzw. kryzysu uchodźczego (inaczej: stan wyjątkowy obowiązujący jako zasada): portal „Wirtualna Polska” podaje wiadomość o zatonięciu około 240 uchodźców i migrantów u wybrzeża Libii. Z tej samej „depeszy” można także dowiedzieć się, że według Rzecznika Międzynarodowej Organizacji ds. Migracji (IOM), Leonarda Doyle'a, „w tym roku 4220 osób straciło życie przy próbie przedostania się łodziami przez Morze Śródziemne"1. Pod tym dość lakonicznym powiadomieniem, informacją pozbawioną komponentu emocjonalnego, widnieje 149 tzw. komentarzy, którym dodatkowo towarzyszą zielone kciuki w górę (thumbs up), wyrażające poparcie dla słów komentującej/komentującego i czerwone w dół, oceniające daną wypowiedź negatywnie. Wśród komentarzy próżno szukać wyrazów empatii, żalu, żałoby, przerażenia czy troski. „To dobra informacja!”, „Mniej islamskich terrorystów na
Katarzyna Bojarska

- adiunkt w Zespole do Badania Literatury i Kultury Późnej Nowoczesności IBL PAN. Autorka licznych tekstów, zainteresowana relacjami sztuki, literatury, historii i psychoanalizy, tłumaczka, redaktorka. Autorka książki Wydarzenia po Wydarzeniu: Białoszewski - Richter - Spiegelman (2012). Współzałożycielka i redaktorka pisma „Widok. Teorie i praktyki kultury wizualnej" www.pismowidok. org.

1 Zob.http://wiadomosci.wp.pl/kat,143276,title,239-migrantowi-uchodzcow-utonelo-na-dwoch-lodziach-przy-wybrzezu-Libii,wid, 18570602,wiadomosc.html (3.11.2016). 
socjalu!",,,Mało ale cieszy”,, Otwieram szampana”. Dwa pierwsze komentarze zdobyły, odpowiednio, 186 zielonych kciuków w górę (przy 28 czerwonych w dół), 174 zielonych kciuków w górę (przy 23 czerwonych w dół), w przypadku pozostałych stosunek entuzjazmu komentujących do niechęci jest porównywalny. Są również nieco bardziej polityczne, a nawet historiozoficzne wynurzenia, ironiczne żarty, podejrzenia, że podobne wiadomości mogą stanowić próbę wyłudzenia współczucia (sic!). Można, rzecz jasna, powiedzieć, że to o niczym nie świadczy, wszystkie wpisy są anonimowe, sygnują je idiotyczne zazwyczaj nicki. Można powiedzieć, że trudno na ich podstawie formułować jakiekolwiek hipotezy o naszej rodzimej „wspólnocie mnemonicznej"2. Można zamknąć zakładkę z wp.pl i nigdy więcej jej nie otworzyć, wychodząc z założenia, że najwyraźniej jest ona adresowana do innych czytelników niż my. (Jakich?) Można byłoby to wszystko zrobić i uspokoić się nieco, gdyby nie fakt, że podobne w tonie, treści, stylu wypowiedzi pod informacją o tym samym zdarzeniu, opublikowaną na portalu społecznościowym Facebook (strona „Historia jakiej nie poznasz w szkole”) wpisują osoby obu płci podpisujące się swoim imieniem i nazwiskiem, a dodatkowo także potwierdzające swoją tożsamość tzw. zdjęciem profilowym. Takich wypowiedzi jest kilkaset ${ }^{3}$. Co można w tym przypadku? Na ilu innych polskich portalach ta sama wiadomość wywołuje falę tych samych nienawistnych i/lub głupich komentarzy? Ile z nich należałoby prześledzić, żeby „coś móc”, żeby pozwolić sobie złożyć to $\mathrm{w}$ jakiś obraz i pokusić się, nawet jeśli nie o interpretację, to może przynajmniej o hipotezę?

Przywołuję ten niestosowny może, ponieważ nazbyt aktualny kontekst, na początek i przeznaczam nań niemało miejsca, ponieważ z przyjętego przeze mnie punktu widzenia wydaje mi się on zasadniczy, niezbędny wręcz dla myślenia o polskiej pamięci i pamięci w Polsce dzisiaj. O tym szczególnym

2 Zob. E. Zerubavel Social Mindscapes, Harvard University Press, Cambridge Mass. 1997, s. 17-18. Za: E. Zerubavel Time Maps. Collective Memory and the Social Shape of the Past, Chicago Univeristy Press, Chicago-London 2003, s. 111, przypis 7.

3 Śledziłam obie te strony poruszona wpisem na portalu Facebook reportera i pisarza, Wojciecha Tochmanna, i dyskusją, która rozgorzała pod jego postem. Przy okazji tej można wspomnieć jeszcze o zdarzeniu o charakterze może nawet bardziej „zbiorowym” czy publicznym, a mianowicie materiale wyemitowanym w TVP Info, w programie Minęła dwudziesta (opublikowanym także na Facebookowej stronie tej stacji), który składał sięze zmontowanych scen agresji i przemocy z udziałem osób o ciemnym kolorze skóry, którym towarzyszył komentarz "Prezydent Gdańska zaprasza imigrantów do swojego miasta. Twierdzi, że w ten sposób ratuje honor Polski w oczach Europy i świata", http://wiadomosci.gazeta.pl/wiadomosci/7,114883,20919664,tvp-info-zmanipulowala-material-o-uchodzcach-czegos-takiego.html (3.11.2016). 
„punkcie widzenia” pamięci i konceptualizowaniu jej chciałabym tu pisać. Pozostanę więc jeszcze na moment przy kwestii migracji, przymusowej migracji, i uchodźstwa. Jak podaje Encyklopedia PWN, kilkanaście milionów Polaków i osób o polskim pochodzeniu mieszka poza granicami państwa ${ }^{4}$. Historia polskiego wychodźstwa sięga XVIII wieku, losów konfederatów barskich, powstańców kościuszkowskich, listopadowych czy styczniowych, od II połowy XIX wieku wraz z dynamicznie rozwijającym się kapitalizmem przede wszystkim w jego wersji przemysłowej dochodzą emigranci ekonomiczni, ofiary polityki zaborców, uchodźcy z Galicji i zaboru rosyjskiego podczas I wojny światowej, przesiedleni, wysiedleni i deportowani podczas II wojny światowej, kilkusettysięczna emigracja w czasach PRL i emigracja po przystąpieniu Polski do Unii Europejskiej w 2004 roku. Czy nie należałoby sądzić, że zbiorowa pamięć Polaków o przymusowej emigracji, ucieczkach, deportacjach sprawi, że będą oni/one reagować przede wszystkim empatią na wieść o tragicznych losach innych migrujących ludzi, ludzi szukających ocalenia, schronienia, azylu politycznego czy choćby poprawy warunków bytowych; że istnienie pamięci w ogóle wytwarza w pamiętających szczególną ramę, w której mogą oni/one zmieścić podobne doświadczenia Innych i inne doświadczenia podobnych sobie. Przypadek „polskiej” reakcji na „kryzys" uchodźczy - również tej reakcji oficjalnej - przeczy albo temu, że pamięć (zbiorowa) działa, albo temu, że w ogóle istnieje.

Istnieje jeszcze inna możliwość: że pamięć bólu, lęku i grozy prowadzi do izolacji pamiętających od świata i od innych pamiętających, zamyka ich w poczuciu, że temu, czego doświadczyli, nie może się równać żadne inne doświadczenie, żadne doświadczenie innych, a nawet, że istnienie (podobnych) doświadczeń innych pamiętających zagraża wyjątkowości, a często nawet obecności ich doświadczenia. Tak ujmowana pamięć to, jak powiada amerykański badacz pamięci, Michael Rothberg, „,forma rywalizacji”, a nawet „walki na śmierć i życie”, w której jest miejsce tylko dla zwycięzców i pokonanych. Zwycięzcy (a zwycięża zawsze ten, o kim pamięć pozostaje, nie zawsze tożsamy z tym, kto wygrał walkę, a nawet wojnę) pamiętają i o zwycięzcach się pamięta. Pokonani zostają pogrążeni w odmętach niepamięci (pogrążeni, choć nie znikają, co jednak zostawia jakąś możliwość powrotu). Tego rodzaju

4 Zob. http://encyklopedia.pwn.pl/haslo/Polonia-emigracja-i-Polacy-w-swiecie;3959692.html (3.11.2016).

5 M. Rothberg Pamięć wielokierunkowa. Pamiętanie Zagłady w epoce dekolonizacji, przeł. K. Bojarska, Wydawnictwo IBL PAN, Warszawa 2015, S. 18, 19. 
logika kulturowa i społeczna, zasadzająca się na walce o uznanie, dyktuje także szczególnego rodzaju koncepcję przestrzeni publicznej, w której dochodzi do starć między z góry ukształtowanymi i zamkniętymi formacjami mnemonicznymi i tożsamościowymi.

Kiedy po II wojnie światowej i zagładzie europejskich Żydów uznano, że pamięć jest koniecznym warunkiem, aby do podobnych tragedii „nigdy więcej" nie dochodziło, to pamięć właśnie okazała się tą siłą, o którą najbardziej należy dbać i od której tak wiele zależy. Jednak dość szybko okazało się przecież, że sama pamięć nie wystarczy, albo wręcz, że pamięć ludobójstwa może stać się narzędziem w brutalnej walce politycznej, uzasadnieniem a wręcz usprawiedliwieniem stosowania i nadużywania siły, niszczenia (także fizycznego) innych ${ }^{6}$. Idąc tropem rozważań autora Pamięci wielokierunkowej, należałoby powiedzieć, że tego rodzaju pamięć - pamięć resentymentalna i rywalizacyjna, związana ze współzawodnictwem ofiar i przekonaniem, że w sferze publicznej nie ma miejsca na współistnienie i wzajemne wspieranie się pamięci różnych grup opresjonowanych - a w zasadzie tego rodzaju podejście do pamięci i traumatycznego dziedzictwa to źródło kryzysów i wojen kulturowych, rozkładu empatii i współczucia, zerwania więzi solidarności między bohaterami różnych historii pełnych przemocy, bólu i cierpienia, między przedstawicielami różnych wyznań, klas, ras, płci. Koncepcja pamięci wielokierunkowej, którą wykłada Rothberg, ma stanowić antidotum na ten stan rzeczy. Koncepcja to, powiedzmy to zaraz, twórcza i utopijna. Jako zakorzeniona w analizie konkretnych aktów pamiętania i konkretnych wytworów kultury, pozwala mieć nadzieję, że te iskry relacyjności, które istnieją i gdzieniegdzie przebłyskują, będą w stanie zaświecić pełnym blaskiem i przywrócić możliwość widzenia połączeń i zależności tym pamiętającym, którzy w więzieniu swojej przeszłości czują się tyle uprzywilejowani, ile samotni.

Wydaje się wręcz oczywiste, że każda zbiorowość pamięta zawsze wobec innego pamiętania albo pamiętania Innego, wciąż jednak nie wiadomo, co wynika z tej relacyjności i na ile może być ona twórcza i produktywna, zarówno w wymiarze etycznym, politycznym, jak i artystycznym. Podstawowa kwestia dotyczy tego, jak wybrnąć z dualizmów (duma/wstyd, my/inni), jak

6 Na marginesie swoich wywodów Rothberg powołuje się na podobną tezę Andreasa Huyssena: „Zuniwersalizowany nakaz «nigdy więcej», a wraz z nim instrumentalizacja pamięci dla celów politycznych, stały się zasłoną zakrywającą okrucieństwa dokonywane w świecie współczesnym", Zob. A. Huyssen Trauma and Memory: A New Imaginary of Temporality, w: World Memory: Personal Trajectories in Global Time, ed. by J. Bennett, R. Kennedy, Macmillan, New York 2003, S. 19. Za M. Rothberg Pamięć wielokierunkowa..., Wstęp, s. 29, przyp. 23. 
otworzyć pamiętanie na pamiętanie, jak odpowiedzialnie zarządzać dynamiką wyłaniania się tych różnych pamięci i powstających afektywnych więzi z przeszłością i (niemniej afektywnych) projekcji na przyszłość.

W Pamięci wielokierunkowej Rothberg dowodzi, że indywidualne akty pamięci, mnemoniczne i krytyczne działania artystyczne, odsłanianie niespodziewanych i zaskakujących analogii czy układów odniesień i powinowactw może posłużyć do zmiany sposobu pamiętania, a zatem do zmiany relacji między pamiętającymi. Wykonanie gestu, który sięga głęboko w struktury pamiętania i pozwala zobaczyć, jak (i kiedy) kształtują się postawy wobec przeszłości, otwiera możliwość powrotu do sytuacji wyboru (pamiętam tak, a nie inaczej; pamiętam to, a nie coś innego), rozszczelnić opowieść o przeszłości w taki sposób, aby udało się powrócić do sytuacji niezrealizowanych, choć np. zapoczątkowanych, wyobrażalnych, potencjalnych, takich które mogły się zdarzyć, ale się nie zdarzyły, albo zdarzyły się, ale nie w pełni się zrealizowały ${ }^{7}$. Istotną konkluzją takiego rozumowania jest przekonanie, że pamięć - szczególnie ta silnie kształtująca tożsamość - nie jest jedna i że zawsze jest już w jakiś sposób „nieczysta” w najlepszym tego słowa znaczeniu, skażona inną pamięcią, i obie te pamięci wzajemnie sobie przydają siły, nie zaś się osłabiają. A przede wszystkim, że zmiana perspektywy, pozwoli być może dostrzec możliwość „nowych form solidarności i nowych wizji sprawiedliwości"8. Czy zatem pamiętać można w sposób (społecznie/politycznie) właściwy, czy pamiętać można „pod włos”, czy pamiętanie może być strategią oporu? Czy pamiętanie może być indywidualne? Czy może nie być indywidualne, skoro zawsze tak mocno wiąże się z cielesnością?

Pozostaje jeszcze istotna kwestia własności. Lęk przed skażeniem inną pamięcią (pamięcią Innej/Innego), to przede wszystkim lęk przed tym, co cudze i co zagraża integralności tego, co własne. Tymczasem z faktu, że posiada się pamięć, nie wynika, że się ją „posiada”, że się ją ma na własność, że - szczególnie pamięć nacechowana traumatycznie - jest czymś, co należy wyłącznie do mnie, a zatem czymś, czego bezwarunkowo muszę strzec i bronić przed przejęciem, zbrukaniem, obrazą etc. Wiele wskazuje jednak na to, że pamięć jako wielowymiarowe i wielogłosowe zjawisko zawsze już jest jednocześnie „własna” i „cudza”: własna, ponieważ związana z moim doświadczeniem - jakiego zapisu przeszłości dokonałam na własny użytek i na

7 Por. A. Azoulay Potential History: Thinking through Violence, "Critical Inquiry” Spring 2013 Vol. 39, No. 3, s. 548-574.

8 M. Rothberg Pamięć wielokierunkowa..., s. 19. 
podstawie własnych przeżyć - i cudza, ponieważ skonstruowana ze znaków, figur, obrazów i narracji wspólnych dla wielu i przez wielu współtworzonych, a także wykorzystywanych do ramowania/ujmowania przeszłości. Jak powiada Rothberg, ,to, co na pierwszy rzut oka wygląda jak moja własność, często okazuje się zapożyczeniem albo adaptacją z historii, która początkowo może wydawać się obca czy odległa"9. Traktowanie pamięci jako czyjejś wyłącznej własności otwiera wyłącznie możliwość nadużyć, roszczeń, zawłaszczeń, kultu ofiary etc. ${ }^{10}$

W kontekście badań nad traumą i zespołem stresu pourazowego (w rozmaitych kontekstach historycznych: Hiroszima, Wietnam, przemoc domowa i seksualna wobec kobiet, Zagłada, kryzys AIDS) Cathy Caruth podkreśla z całą mocą, że trauma z a w s z e należy do w s zy s t k i ch jako wezwanie (do odpowiedzialności za zadanie cierpienia) i zadanie (wysłuchania, przepracowania $)^{11}$. W tym sensie - a także ze względu na szczegółowo analizowaną przez autorkę w Unclaimed Experience specyfikę tego zjawiska - nikt nie jest jej wyłączną właścicielką/właścicielem, spadkobierczynią/spadkobiercą czy nosicielką/nosicielem. Co więcej, trauma związana z danym wydarzeniem często wyłania się w kontekście zdarzenia innego, pozornie niezwiązanego (o ile o wydarzeniach historii powszechnej można w ogóle myśleć jako o „niezwiązanych”). Dowodzi tego - nie wiem, czy świadomie - sama Caruth we wstępie do tomu zbiorowego z 1995 roku, Trauma. Explorations in Memory, który zwykło się kojarzyć z wzmożonym zainteresowaniem pamięcią Zagłady. W pierwszym akapicie pisze bowiem, że zainteresowanie „traumą" jako reakcją na przemoc polityczną i historyczną pojawia się w szczególnym momencie wojny w byłej Jugosławii i kryzysu imperialistycznej polityki USA ${ }^{12}$. Można tak jednak myśleć tylko wówczas, kiedy zrezygnuje się z wyobrażenia o pamięci i pamięci zbiorowej jako szczelnym i spójnym zapisie przeszłości i jej transferze do teraźniejszości, a zacznie myśleć o niej jako o porowatej i relacyjnej wymianie między teraz i wtedy, między ty i ja, między my i wy etc., zbiorem praktyk, gestów i figur, które przeszłość nie tylko rejestrują, ale także uwspólniają i re-animują na potrzeby każdej teraźniejszości. Przestrzeń

9 Tamże.

10 Zwraca na to uwagę m.in. historyk idei Dominick LaCapra. Zob. Historia w okresie przejściowym, przeł. K. Bojarska, Universitas, Kraków 2009.

11 Zob. C. Caruth (ed.) Trauma. Explorations in Memory, Johns Hopkins University Press, Baltimore 1995.

12 Tamże, s. vii. 
publiczna będzie wówczas przestrzenią stawania się, wypracowywania stanowisk, wzajemnej wymiany i „zanieczyszczania”, a nie agonem, w którym ścierają się gotowe stanowiska, szczelnie zamknięte formy pamięci.

\section{Jak dzieci}

Dla takiego ujęcia przestrzeni publicznej i pamięci będzie nie od rzeczy przywołanie krytyki pamięci, jaką w Tysiącu plateau zaproponowali Gilles Deleuze i Felix Guattari. W 10 plateau piszą o „większości” jako stanie albo wzorcu, wobec którego wszystko inne jest mniejszością. Tą zasadzającą się na dominacji większością jest „biały dorosły mężczyzna”13, a zatem wszystko, co niemęskie, niedorosłe i innego niż biały koloru skóry, jest mniejszością. „Stawanie się mniejszościowym jest sprawą polityczną i odwołuje się do całej pracy władzy, do czynnej mikropolityki. To przeciwieństwo makropolityki czy nawet Historii"14. Historia jest zatem wyłącznie większościowa, zaś to, co jawi się jako historia mniejszości, wyłania się zawsze wyłącznie w relacji wobec większości i na jej prawach. W takiej ramie człowiek „ustanawia się [...] jako olbrzymia pa mięć "15: męska, biała, większościowa, zamknięta, a jednocześnie będąca absolutnym przeciwieństwem stawania się. Oczywiście zarówno dzieci, jak i kobiety i ludzie o innym niż biały kolorze skóry doświadczają, a więc wytwarzają i posiadają w s p o m n i e n i a. Te jednak gromadzi się w archiwum pamięci, które jest instancją odpowiednio je formatującą, organizującą i nazywającą, by mieć nad nimi makropolityczną władzę, pisać ich historię. Z perspektywy interesującej nas tu pamięci wielokierunkowej i przestrzeni publicznej jako miejsca stawania się mikropolityczny potencjał „wspomnień dziecięcych” - nazwijmy je tak ogólnie, w pewnym uproszczeniu - ma niebanalne znaczenie.

Analizie dziecięcych wspomnień Sigmunda Freuda zawdzięczamy wykładnię złożonej i paradoksalnej natury pamięci. W pamięci - pisał autor Objaśniania marzeń sennych - przechowują się treści nie ze względu na swoją doniosłość dla życia i psychiki pamiętających, ale ze względu na „związki kojarzeniowe" z treściami, które zostały stłumione; dynamika pamięci zasadza się na afektywnie stymulowanych przemieszczeniach, przesunięciach,

G. Deleuze, F. Guattari Tysiq̨c plateau, bez. tłum., Fundacja Bęc Zmiana, Warszawa 2015, s. 352.

Tamże, s. 353.

15

Tamże, s. 354. 
substytucjach, asocjacjach i wreszcie zniekształceniach czy pomyłkach („pamięć spudłowała” - pisze Freud ${ }^{16}$ ). Freudowska „pamięć”, ze szczególnym uwzględnieniem wspomnień przesłonowych ${ }^{\mathbf{1 7}}$, jawi się jako pamięć zawsze w ruchu: wielotorowy i wieloczasowy proces kojarzenia i jako taka stanowi znakomitą matrycę dla Rothbergowskiej koncepcji i przyczynek do postulowanej zmiany paradygmatu w konceptualizowaniu pamięci zbiorowej ${ }^{\mathbf{1 8}}$.

Najbardziej zagadkowym elementem dynamiki pamiętania był dla Freuda fakt, że banalne doświadczenia zostają zachowane, natomiast zdarzenia o dużej wadze i istotnym komponencie afektywnym znikają (ulegają stłumieniu). Te pierwsze, uznał, pełnią rolę maskującą, zasłaniają to, co w pewnym sensie nie mieści się w (aktualnych) ramach pamiętania. I choć nie mieści się i znika, nie ginie bezpowrotnie, ale przesłonięte staje się potencjalnie możliwe do otworzenia przy pewnej konfiguracji psychicznej. Czasowa relacja między tymi wspomnieniami może być różnoraka, bowiem projekcje z tego, co zostało stłumione, oddziałują zarówno równocześnie wstecz, jak i z opóźnieniem ${ }^{19}$. Na tę złożoną siatkę relacji czasowych nakłada się przeświadczenie - wynikające z poszczególnych studiów przypadków Freuda - że to, co zostaje w pamięci, zarówno zasłania, jak i odsłania to, co z niej znika. Nic nie znika bowiem bezpowrotnie ${ }^{\mathbf{2 0}}$, wszystkie doświadczenia zostają uwikłane w system połączeń (jako to, co pamiętane i jako to, co zapomniane) i trafiają w przestrzeń wymiany między świadomością i nieświadomością. Pamięć przesłonowa może wydawać się fałszywa o tyle, o ile jej właściwym sensem jest to, co zakrywa. Jednak, jak twierdzi Rothberg, autentyczność i prawda tej

S. Freud Psychopatologia życia codziennego, przeł. W. Szewczuk, PWN, Warszawa 2013, s. 82.

17 Deckerinnerung według polskiego przekładu Jeana Laplanche’a i Jean-Bertranda Pontalisa to „Wspomnienia przesłonowe”. W polskim przekładzie Psychopatologii życia codziennego Sigmunda Freuda tłumacze zdecydowali się na „wspomnienia maskujące”. W tekście posługuję się zarówno wspomnieniami „przesłonowymi” czy "maskującymi”, jak i „pamięcią przesłonową”. Por. J. Laplanche, J.-B. Pontalis Słownik psychoanalizy, przeł. E. Modzelewska, E. Wojciechowska, Wydawnictwa Szkolne i Pedagogiczne, Warszawa 1996; S. Freud Psychopatologia....

18 Samo przejście od psychiki jednostkowej do rozważań o zbiorowościach nie jest niczym oczywistym, z czego zarówno Rothberg, jak i autorka tego szkicu zdają sobie sprawę. Nie chodzi tu jednak o ustanowienie naukowej, psychologicznej czy psychiatrycznej wykładni, ale o swoisty eksperyment myślowy, o próbę podważenia i naruszenia dominującej narracji o pamięciach zbiorowych i jej związkach z tożsamościami. S. Freud Psychopatologia... 
pamięci polegają przede wszystkim na umożliwieniu „wglądu w jednostkowe i zbiorowe procesy wytwarzania znaczeń", a także na ujawnieniu, że wszelkie akty pamiętania zasadzają się na koniecznych konfliktach i negocjacjach, przemieszczeniach i substytucjach ${ }^{\mathbf{2 1}}$.

Mit o osobności i czystości pamięci musi zatem pozostać mitem. Jej otwartość, relacyjność i anachroniczność, a nawet swego rodzaju absurdalność są faktem i wyzwaniem. Zaskakujące korespondencje i sojusze pamięci (różnych pamięci, pamięci różnych podmiotów), choć mogą wydawać się ryzykowne okopanym w poczuciu zagrożenia „pamiętającym”, stanowią - jak się zdaje - jedyną drogę wyjścia z narastającego kryzysu. Mogą one otworzyć przestrzeń i pole popisu dla wyobraźni. Tylko dzięki niej można wydobyć i od-tworzyć przeciw-tradycję, która będzie podłożem walki z niesprawiedliwością, przemocą. Sztuka często pełni funkcję takiej wielokierunkowej projekcji, która w dodatku, w zależności od momentu, kiedy zjawia się w świecie odbiorców, wywołuje inny rodzaj projekcji, inny zestaw pamięci i inny układ kierunków, inne doświadczenie zarówno estetyczne, jak i historyczne. Sztuka nie tyle więc może, ile wręcz musi być anachroniczna, jednocześnie spóźniona (wobec tego, co aktualnie dzieje się na świecie, co „boli” jako na gorąco doświadczana historia - by posłużyć się sformułowaniem Fredrica Jamesona) i przed czasem (zapowiada to, co się jako historia zapisze i zaboli). Nawet bowiem, jeśli sztuka jest pozornie o czymś konkretnym, jakiejś doraźności, którą „na gorąco” komentuje, na którą reaguje, która ją powołuje do życia, to i tak zawsze jest już (i jeszcze) o czymś innym²2. Tego rodzaju korespondencje i sojusze - często odczytywane jako prowokacje - pojawiają się w polu sztuki, migoczą jako możliwość interpretacji porównawczych. Często jednak pozostają niezrealizowane.

\section{Sojusz przegapiony}

W ostatnich latach w Polsce pojawia się wiele przejawów refleksji na temat okresu tuż po II wojnie światowej na ziemiach polskich: zarówno w perspektywie refleksji teoretycznej (Andrzej Leder Prześniona rewolucja), artystycznej (Zaraz po wojnie, Zachęta Narodowa Galeria Sztuki, kur. Agnieszka Szewczyk,

21 M. Rothberg Pamięć wielokierunkowa..., s. 33.

22 W tym kierunku zmierzała moja interpretacja wybranych prac Mirona Białoszewskiego, Gerharda Richtera i Arta Spiegelmana, którą w kontekście pamięci Zagłady wyłożyłam w książce Wydarzenia po Wydarzeniu, Wydawnictwo IBL PAN, Warszawa 2012. 
Joanna Kordjak-Piotrowska), historyczno-reporterskiej (Magdalena Grzebałkowska 1945 Wojna i pokój), historycznej (Marcin Zaremba Wielka trwoga) i na tym lista się nie kończy. A jednak, kiedy w 2015 roku warszawskie Muzeum Sztuki Nowoczesnej w otwartym na miasto i publiczność gmachu Emilki pokazało fascynującą wystawę After Year Zero: Powojenny uniwersalizm i geografie wspótpracy ${ }^{23}$ autorstwa pary niemieckich kuratorów, Annett Busch i Anselma Franke, a także wspólnie z berlińskim Haus der Kulturen der Welt zorganizowało minikonferencję i wydało towarzyszącą wystawie książkę, nie trafiła ona na podatny grunt, nie trafiła do dyskusji, nie zainteresowała polskiej publiczności pamiętającej.

Projekt Busch i Franke wyrósł z kilkuletniej współpracy badaczy i artystów zainteresowanych dekolonizacją: przejściem od antykolonializmu przez niepodległość do postkolonializmu, a zaowocował hybrydyczną narracją o powojniu, w której na równych prawach funkcjonują ze sobą dzieła sztuki współczesnej, filmy, dyskurs akademicki (historyczny i teoretyczny), dokumenty archiwalne i wszelkiego rodzaju wytwory kultury wizualnej, w tym kultury popularnej. Wystawa traktowała o rozgrywającej się w pozaeuropejskich topografiach dekonstrukcji uniwersalizmu jako wytworu zachodniej nowoczesności, wytworu-daru eksportowanego do tzw. Trzeciego Świata. Chodziło zatem przede wszystkim o to, w jaki sposób dokonać twórczego przechwycenia i przepisania idei „uniwersalizmu” poza jej większościowym, dominującym przejawem. Chodziło także, jak powie Franke, o sprowadzenie do jednej przestrzeni dyskursywnej (przestrzeni wystawy) takich narracji, obrazów, stanowisk etc., które wydawały się z pozoru do siebie nieprzystające, sprzeczne czy wręcz sobie wrogie ${ }^{24}$.

Wystawa pyta zarówno o to, dla kogo jest uniwersalizm, kto decyduje o aktualności projektu i kto ma prawo w jego imieniu mówić, a także kto ma prawo do nowoczesności i do jakiej nowoczesności, jak kształtuje się relacja między kolonizującymi i kolonizowanymi. Pokazuje, jak przebiegały ścieżki wpływów, kto z kim współpracował i czym się inspirował, jak np. wyglądała socjalistyczna niepodległość Ghany, jak modernizował się ten kraj, wydobywając się z mroków kolonialnej przeszłości (Otolith Group) i jaki był koszt tej

Zob. http://artmuseum.pl/pl/wystawy/after-year-zero, zob. także After Year Zero. Geographies of Collaboration, ed. by A. Busch, A. Franke, University of Chicago Press, Chicago 2015.

24 Zob. Ontological Laboratory in the Making: "After Year Zero" and the Resetting of Historical Imagination, Annett Busch and Anselm Franke in conversation with Katarzyna Bojarska, http:// pismowidok.org/index.php/one/article/view/283/472 (3.11.2016). 
modernizacji. To komentarz to europejskiego uwikłania w projekt kolonialny i w tym sensie niemożliwości oddzielenia historii Europy do historii Afryki (również projektu Unii Europejskiej) i vice versa. Najmocniejszym bodaj głosem w tym kontekście jest film found footage Yervanta Gianikiana i Angeli Ricci Lucchi, zatytułowany Pays barbare, opowieść o inwazji Mussoliniego na Etiopię i próba przepisania narracji o początku II wojny światowej, która zamiast w 1939 roku w Polsce miała zacząć się cztery lata wcześniej na innym kontynencie. Gest co najmniej prowokujący do wyobrażenia sobie historiografii, w której możliwe byłoby takie przemieszczenie (czasowe i przestrzenne). Jednak polska wyobraźnia zbiorowa nie zadrżała. Nie zadrżała ani na myśl o tym, że może być elementem większej, jeszcze bardziej wielowątkowej i wielogłosowej opowieści, ani na myśl, że znajduje się wśród innych podbitych, kolonizowanych i usiłujących się modernizować zbiorowości.

Jak celnie zauważył Jakub Majmurek w tekście poświęconym wystawie, uważna lektura wystawy pozwala zobaczyć w niej zachętę do rewizji historii PRL (także z jej rolą jako zrealizowanego eksperymentu socjalistycznego dla powojennej historii krajów afrykańskich) poza lokalnością tej opowieści, poza dostępnymi i przyjętymi wzorcami opowiadania (i doświadczania), jako naszej „przygody z nowoczesnością” w perspektywie globalnej. Pisze np. „zupełnie wbrew intuicjom wynikającym z naszego doświadczenia historycznego - dla ludów globalnego Południa, to Moskwa albo Hawana mogły oferować bardziej atrakcyjną formę nowoczesności, szanse (najczęściej iluzoryczne) na negocjacje bardziej podmiotowych form uczestnictwa w nowoczesnym projekcie"25. Wskazuje też na nieobecne w zbiorowej pamięci tego okresu, pasjonujące elementy tej historii, jak epizody współpracy komunistycznego Wschodu z Zachodem, np. udział polskiej szkoły planowania SGPiS w rozwoju postkolonialnych krajów afrykańskich ${ }^{26}$. Dlaczego zatem - także mimo udziału polskich twórców w wystawie - przeszła ona niemal bez echa?

Wydaje się, że jedną z możliwych odpowiedzi na to pytanie jest swego rodzaju nerwica narodowa, której zakładniczką jest polska pamięć zbiorowa; nerwica tak znakomicie zobrazowana m.in. przez Witolda Gombrowicza w Trans-Atlantyku i przez Marka Koterskiego w Dniu świra. Zatrzaśnięcie

25 J. Majmurek Żyć w jednym świecie, „Dwutygodnik”, http://www.dwutygodnik.com/artyku|/6013-zyc-w-jednym-swiecie.html (3.11.2016). "przewodnika interdyscyplinarnego" Polska \& Azja. Od Rzeczpospolitej Szlacheckiej do Nangar Khel, red. M. Cegielski, Fundacja Malta, Poznań 2012. 
w dusznej, krępującej formie, w której odbywa się wyłącznie rozmowy z samym sobą, rozmowy o sprawach ważnych wyłącznie dla nas samych i dla naszej sprawy. Ta nerwica sprawia, że wszystko bierze się do siebie i jako swoje przechowuje, unikając jednocześnie relacji z innymi i ich sprawami. $\mathrm{Na}$ tę nerwicę pomóc może wyłącznie terapia realizowana nie inaczej niż poprzez sztukę, i nie bezboleśnie. Zasadnicze jest bowiem zrozumienie idei uniwersalizmu i historii uniwersalnej, w które czy tego chcemy, czy nie, jesteśmy uwikłani, także jako twórcy ruchu o nazwie „Solidarność”; zrozumienie i poczucie się do odpowiedzialności za nie. Jak znakomicie ujęła to Susan Buck-Morss

Kiedy myślimy o historii uniwersalnej jako o projekcie, który sięga poza wprowadzanie korekty do eurocentrycznego trybu pisania historii czy wszelkiej innej hegemonii w odniesieniu do przeszłości, jej celem będzie ni mniej, ni więcej tylko inna organizacja świata, oparta na dzieleniu się i solidarności, uznaniu, ale nie na afirmowaniu różnicy. Musi ona bazować na takiej strukturze pamięci zbiorowej, w której nie ma miejsca dla własności i odrębności poszczególnych „historii”.To pokiereszowana idea i bezwzględnie należy pamiętać o tych epizodach okaleczeń, jak również o momentach pozytywności. ${ }^{27}$

W tym sensie właśnie historia dekolonizacji globalnego Południa czy rozbitkowie u wybrzeży Libii i ci, którzy płyną na łodziach, albo szmuglowani w innych nieludzkich warunkach, szukają schronienia, pracy, życia, to także nasza sprawa i nasza historia. Projektom historii uniwersalnej, jak widzi ją autorka Hegel, Haiti i historia uniwersalna, czy pamięci wielokierunkowej, jak opisuje ją Rothberg, przyświeca podobny cel: przemyślenie walki o uznanie i wypracowania nowych formuł sprawiedliwości i wzorców wyobraźni, które pozwolą inaczej widzieć i przyswajać przeszłość, rozszerzą pole wrażliwości i empatii na innych, nawet tych najbardziej innych, którzy dotąd należeli do jakiejś innej historii, a ich historia nie należała nigdzie. Ponowne przemyślenie nieoczywistej relacji między pamięcią i tożsamością nie może odbyć się bez etyki odpowiedzialności. A tej warto uczyć się choćby z myśli feministycznej.

27 Solidarność w historii - ludzie i idee. Susan Buck-Morss w rozmowie z Katarzyną Bojarską, "Teksty Drugie" 2014 nr 5, s. 210. 
Jak powiada, podążając tropem teorii lektury Paula de Mana, Teresa de Lauretis, należy otworzyć się na czytanie, interpretację, a więc i dezinterpretację. Czytanie bowiem w oczywisty sposób naraża na spotkanie z innością, tym, czego nie rozumiemy i co się wymyka dostępnym nam ramom interpretacji i rozumienia, a także temu, co pamiętamy. „Doświadczenie porażki w procesie interpretacji potrafi wstrząsnąć podstawami hermeneutycznej pewności siebie i pewności mojej pozycji podmiotowej"28. To wydarzenie o znaczeniu trudnym do przecenienia: wydarzenie, w którym mierzę się z innością i osobnością w sobie samej (czymś nieoczekiwanym, czymś, co wymyka się spod kontroli, czymś - być może skandalicznym, a także innością i heterogenicznością świata ${ }^{29}$. Potrzeba nam zatem pogłębionej i konsekwentnej autoanalizy a także wyzbycia się lęku przed dezinterpretacją (również otwarciem na pomyłkę w nas samych, pomyłkę pamięci, pomyłkę tożsamości - być może jestem bardziej kimś innym, niż myślę, że jestem). Jeśli zrozumiem, że mogę błędnie odczytać innych ludzi, zdam sobie sprawę, że również moje samorozpoznanie może być omyłkowe. Mylnie odczytuję bowiem sens tekstu własnej pamięci i doświadczenia. Interpretacja to czynność o charakterze politycznym; doświadczenie stające twarzą w twarz z ideologią ${ }^{30}$.

28 T. de Lauretis Figures of Resistance. Essays in Feminist Theory, University of Illinois Press, Chicago 2007 , s. 255 .

29 Tamże.

30 Tamże, s. 258. 


\section{Abstract}

\section{Katarzyna Bojarska}

THE INSTITUTE OF LITERARY RESEARCH OF THE POLISH ACADEMY OF SCIENCES (WARSAW)

Polish Multidirectional Memory?: He Who Does Not Remember with Us, Does Not Remember against Us Either

Bojarska tackles the current crisis of compassion and empathy that arises from the crisis of certain forms of collective memory. She argues that the concept of collective memory should be abandoned and that we should embrace relational or multidirectional memory. Crucial in this model is the conviction that memory is never one nor univocal, but rather an amalgam of earlier acts and representations. Bojarska calls for ethics of responsibility when it comes to establishing a collective identity that is closely linked to the past.

\section{Keywords}

collective memory, collective identity, relational memory, multidirectional memory, ethics of responsibility 